\title{
Safety of Nuclear Waste Repositories
}

\author{
Wolfgang Hummel* and Jürg W. Schneider ${ }^{\mathrm{a}}$
}

\begin{abstract}
A short overview is given of different nuclear waste repository concepts, followed by a more detailed discussion of Swiss radioactive waste management planning. Waste types and characteristics and the concept for their disposal are summarised. The safety concept involving a multi-barrier system is illustrated with the example of vitrified high-level waste. Important geochemical parameters and processes for repository safety are listed, and some selected aspects concerning porewater chemistry, solubility limits and sorption of radionuclides are discussed in detail with specific examples.
\end{abstract}

Keywords: Radioactive waste $\cdot$ Repository safety $\cdot$ Solubility $\cdot$ Sorption · Water chemistry

\section{Introduction}

Worldwide a significant amount of nuclear waste exists today, and will continue to arise in the future. This waste stems from a range of sources, including electricity production in nuclear power plants and applications of radioactive substances in medicine, industry, and research. A key principle of radioactive waste management is that the waste must be disposed of in such a way that the safety of man and the environment is ensured. This principle is also reflected in the legal framework in most countries, e.g. in Switzerland in the recently revised Nuclear Energy Law [1]. It is widely accepted that one possibility to meet the obligation to dispose of radioactive waste in such a way that the safety of man and the environment can be ensured is to emplace

${ }^{*}$ Correspondence: Dr. W. Hummel

Laboratory for Waste Management

Paul Scherrer Institut (PSI)

$\mathrm{CH}-5232$ Villigen $\mathrm{PSI}$

Tel.: +41563102994

Fax: +4156310 2821

E-Mail: wolfgang hummel@psi.ch

aNational Cooperative for the Disposal of Radioactive

Waste (Nagra)

Hardstrasse 73

$\mathrm{CH}-5430$ Wettingen the waste in a carefully sited and well-designed geological repository. In fact, in Switzerland a Government Working Group with a mandate to evaluate different waste management concepts stated in their final report [2]: "Geological disposal is the only method for disposing of radioactive waste which meets the long-term safety criterion (up to more than 100,000 years)". This is also reflected in the Swiss Nuclear Energy Law, which states that radioactive waste has to be disposed of in a deep geological repository [1].

Internationally, a large number of nuclear waste repositories for low-level waste (LLW), low- and intermediate-level waste (L/ILW) and intermediate-level waste (ILW) have been in operation for many years, e.g. in Finland, France, Germany, Japan, Spain, Sweden, the UK, and the USA. Mainly for technical reasons, the situation is different for spent fuel (SF) and vitrified high-level waste (HLW) from reprocessing of spent fuel. These waste types are currently in interim storage facilities to allow the radiogenic heat production to decline to such levels that the waste can be disposed of in deep geological repositories so that temperatures stay below specification limits set to ensure the good performance of the engineered barriers (specifically bentonite, a natural clay-based material that is foreseen in many SF/HLW repository concepts as a buffer material between the waste canisters and the host rock). Typical required minimal interim storage times are in the order of 40 years. Even though there is no repository for SF or HLW in operation yet, detailed concepts have been developed and refined over the last years, and implementation is well under way in several countries, notably in Finland, where the decision-in-principle was taken by parliament to construct a SF repository in Olkiluoto. A few selected examples for different repository concepts for SF and HLW are given in Table 1. It is beyond the scope of this article to discuss these in detail here; instead, the interested reader is referred to the references given in Table 1. A broader overview of national repository concepts for all waste types is given by, for example, Witherspoon and Bodvarsson [10].

\section{Swiss Radioactive Waste Management Planning}

\subsection{Overview}

A schematic overview of the sources of radioactive waste in Switzerland and the waste management strategy considered is presented in Fig. 1.

Radioactive waste in Switzerland arises from the operation and decommissioning of nuclear power plants, from the fuel cycle of the power plants, and from medicine, industry, and research. To estimate waste volumes and inventories, in the recent disposal feasibility study for SF, HLW \& ILW, Project Entsorgungsnachweis ([8] and references therein), a 60-year operational lifetime of the Swiss power plants was assumed, corresponding to a total nuclear power production of $192 \mathrm{GWa}(\mathrm{e})$. A part of the spent fuel from nuclear power production is reprocessed. The fissile material recovered in the process is used to fabricate new fuel elements. The wastes arising from reprocessing (HLW and ILW) are returned to Switzerland. The Swiss electricity utilities have placed contracts with BNFL (UK) and COGEMA (France) for the reprocessing of spent fuel from about $40 \mathrm{GWa}(\mathrm{e})$ 
Table. 1. Examples for different repository concepts for SF/HLW

\begin{tabular}{|c|c|c|c|c|c|c|c|}
\hline Country & $\begin{array}{l}\text { Organisa- } \\
\text { tion }\end{array}$ & Waste & Canister & Buffer & Host rock & Concept & References \\
\hline Belgium & ONDRAF & SF / HLW & Steel & Bentonite & Boom Clay & Horizontal emplacement in tubes & [3] \\
\hline Finland & POSIVA & SF & $\begin{array}{l}\text { Copper with } \\
\text { steel insert }\end{array}$ & Bentonite & Crystalline basement & $\begin{array}{l}\text { Individual vertical boreholes in the } \\
\text { floor of emplacement tunnels }\end{array}$ & {$[4]$} \\
\hline France & ANDRA & HLW & Steel & Bentonite & Callovo-Oxfordian Clay & $\begin{array}{l}\text { Short horizontal tunnels starting } \\
\text { from main gallery }\end{array}$ & [5] \\
\hline Japan & $\mathrm{JNC}$ & HLW & Steel & $\begin{array}{l}\text { Bentonite- } \\
\text { sand }\end{array}$ & $\begin{array}{l}2 \text { host rocks conside- } \\
\text { red: 'hard' / 'soft' }\end{array}$ & $\begin{array}{l}2 \text { concepts considered: horizontal } \\
\text { / vertical }\end{array}$ & [6] \\
\hline Sweden & SKB & SF & $\begin{array}{l}\text { Copper with } \\
\text { steel insert }\end{array}$ & Bentonite & Crystalline basement & $\begin{array}{l}\text { Individual vertical boreholes in the } \\
\text { floor of emplacement tunnels }\end{array}$ & [7] \\
\hline $\begin{array}{l}\text { Switzer- } \\
\text { land }\end{array}$ & Nagra & $\begin{array}{l}\text { SF / HLW / } \\
\text { ILW }\end{array}$ & Steel & $\begin{array}{l}\text { SF / HLW: } \\
\text { Bentonite } \\
\text { ILW: Cement- } \\
\text { based mortar }\end{array}$ & Opalinus Clay & Horizontal emplacement & [8] \\
\hline USA & DoE & SF / HLW & Steel & None & Tuff & $\begin{array}{l}\text { Horizontal emplacement in host } \\
\text { rock above the water table, use of } \\
\text { drip shields }\end{array}$ & [9] \\
\hline
\end{tabular}

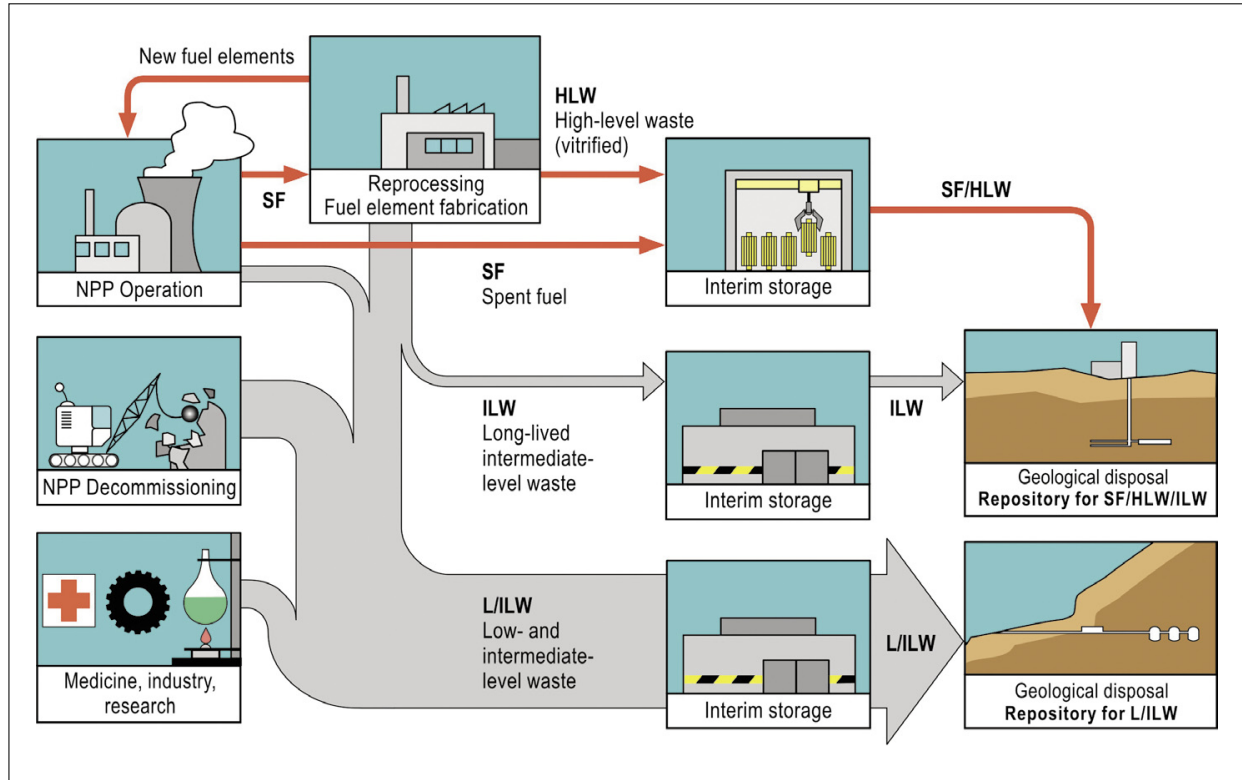

Fig. 1. Overview of the sources of radioactive waste in Switzerland and the waste management strategy considered

of nuclear power generation. In Project Entsorgungsnachweis it was assumed that the spent fuel not covered by the existing reprocessing contracts will be disposed of without reprocessing [11].

Prior to disposal, SF and HLW will be held in interim storage for a period of at least 40 years, in order to allow radiogenic heat production to decrease. The interim storage facilities ZWILAG [12], ZWIBEZ [13], BZL [14], a new wet storage facility for SF currently under construction at the Gösgen nuclear power plant, and others [15] provide enough capacity for storage of all radioactive wastes of Swiss origin.
Two types of repositories are foreseen in Switzerland:

- A repository for the disposal of lowand intermediate-level waste (L/ILW [16]) arising from the operation and decommissioning of Swiss nuclear power plants, from medicine, industry and research and from those operations in reprocessing that produce only low-level technological waste. The repository will consist of mined caverns located in a suitable host rock.

- A repository for the disposal of SF, HLW, and long-lived ILW (primarily resulting from fuel reprocessing). The repository will be located in a deep geological formation and will consist of a tunnel system for SF and HLW and separate tunnels for ILW, with access via a ramp and/or vertical shaft, depending on the repository location and the host rock that is selected.

As an example, the possible layout for a deep geological repository for SF/HLW/ ILW in Opalinus Clay is shown in Fig. 2.

\subsection{Waste Types and Character- istics and the Concept for their Disposal}

\subsubsection{Spent Fuel and Vitrified High-level Waste}

According to Project Entsorgungsnachweis, the SF elements will be emplaced in steel disposal canisters with a diameter of about $1 \mathrm{~m}$ and a length of about $4.6 \mathrm{~m}$. The vitrified HLW packages will be placed in steel disposal canisters with a diameter of about $1 \mathrm{~m}$ and a length of about $2 \mathrm{~m}$. The individual canisters will be emplaced coaxially in $800 \mathrm{~m}$ long horizontal emplacement tunnels with a diameter of $2.5 \mathrm{~m}$ (Fig. 2 ). They will be completely surrounded by bentonite, with a horizontal distance of $3 \mathrm{~m}$ between canisters [8].

\subsubsection{Long-lived Intermediate-level Waste}

A variety of long-lived ILW types are produced as a result of reprocessing of SF. These wastes include metals, inorganic materials, and organics (Table 2). They are mixed with either cementitious materials or, in one case, bitumen and placed in steel and fibre-cement waste drums rang- 


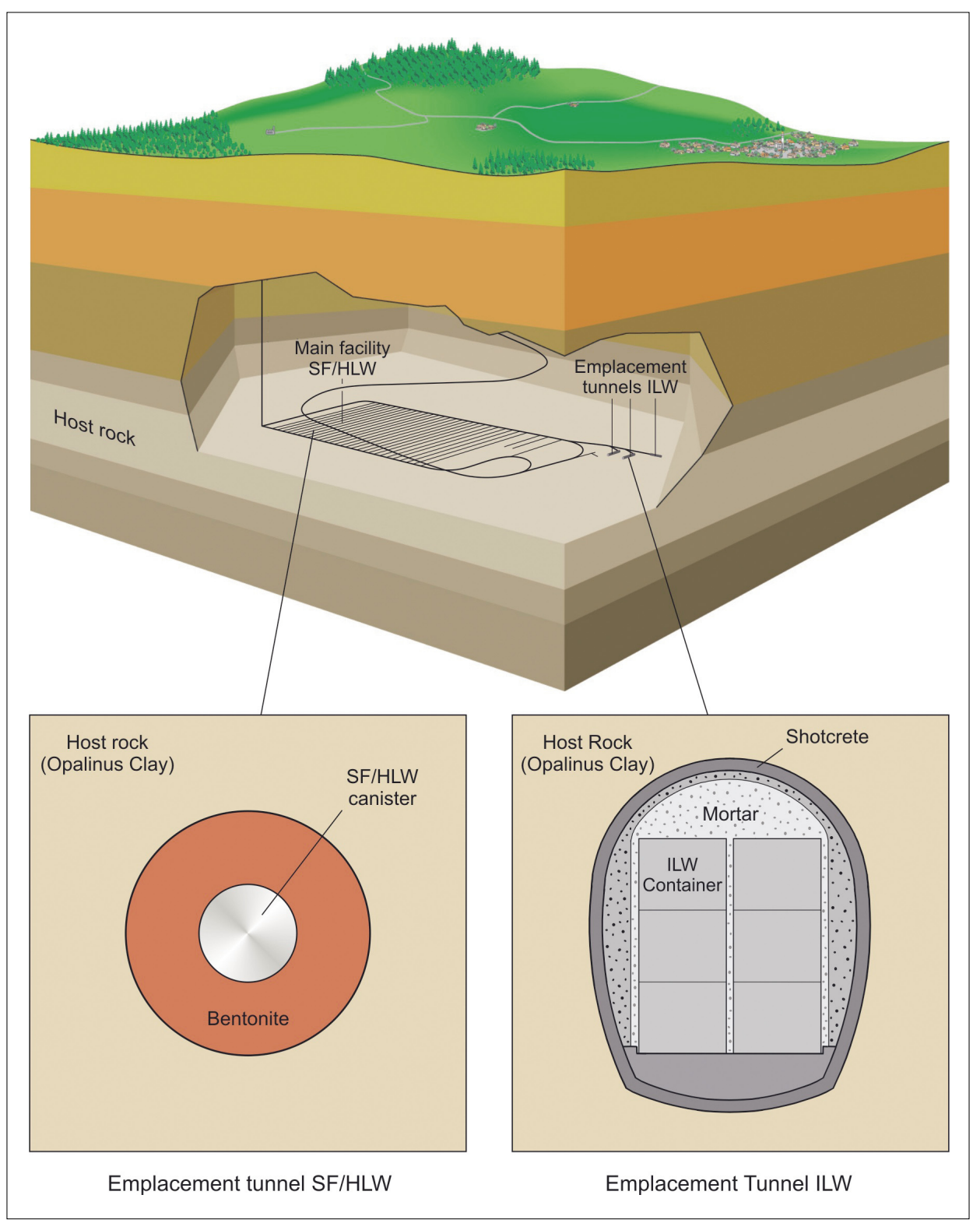

Fig. 2. Possible layout for a deep geological repository for SF/HLW/ILW in Opalinus Clay. Taken from [8].

Table. 2. The total inventories of materials in the ILW, excluding emplacement containers. Taken from [8].

\begin{tabular}{|c|c|c|c|}
\hline Material & Mass [kg] & Material & Mass [kg] \\
\hline Metals & $8.9 \times 10^{5}$ & High mol. wt. organics & $7.4 \times 10^{4}$ \\
\hline Steels & $5.6 \times 10^{5}$ & Bitumen & $4.7 \times 10^{4}$ \\
\hline $\mathrm{Al} / \mathrm{Zn}$ & $3.4 \times 10^{3}$ & Cellulose & $5.1 \times 10^{2}$ \\
\hline Inconel & $1.6 \times 10^{4}$ & Plastics & $2.7 \times 10^{4}$ \\
\hline Zircaloy & $3.0 \times 10^{5}$ & Low mol. wt. organics & $8.4 \times 10^{2}$ \\
\hline Other & $3.2 \times 10^{3}$ & Detergents & $7.5 \times 10^{2}$ \\
\hline Inorganics & $2.2 \times 10^{6}$ & Flocculants & 6.5 \\
\hline Salts & $3.0 \times 10^{4}$ & Complexing agents & $9.1 \times 10^{1}$ \\
\hline Glass & $3.1 \times 10^{2}$ & & \\
\hline Cementitious material & $2.1 \times 10^{6}$ & & \\
\hline Other & $2.3 \times 10^{3}$ & Total & $3.1 \times 10^{6}$ \\
\hline
\end{tabular}

ing from 2001 drums to $1.5 \mathrm{~m}^{3}$ containers. The ILW drums will be placed in concrete emplacement containers, with a cementitious mortar used to fill the void spaces around the drums. The void spaces between the emplacement containers and the tunnel walls will also be filled with a cementitious mortar (Fig. 2)

\subsubsection{Low- and Intermediate-level Waste}

Due to the wide range of their origins (see Fig. 1), the variety of L/ILW types is even greater than for ILW. However, qualitatively L/ILW has similar non-radiological properties to ILW. L/ILW is placed in similar waste drums, which are placed in concrete emplacement containers, and the void spaces around the drums as well as the spaces between the emplacement containers and the tunnel walls will also be filled with a cementitious mortar.

\section{Safety Concept}

The safety concept explains how the repository system provides long-term safety. This usually involves a multi-barrier system where each barrier contributes to safety by providing multiple safety-relevant functions. Fig. 3 illustrates the case of vitrified HLW, where the innermost barrier (the solidification matrix) is shown at the top and the outermost barrier (the geosphere with the host rock) is shown at the bottom. For each barrier, the safety-relevant functions are given, and it is indicated by which processes each function operates. Similar functional descriptions of the safety barrier system for SF and long-lived ILW are given in [8].

Such a repository system provides the following safety functions:

- Isolation of the Waste from the Human Environment: The safety and security of the waste, including fissile material, is ensured by placing it in a repository located deep underground, with all access routes backfilled and sealed, thus isolating it from the human environment and reducing the likelihood of any undesirable intrusion and misapplication of the materials. Furthermore, the absence of any currently recognised and economically viable natural resources and the lack of conflict with future infrastructure projects that can be conceived at present reduce the likelihood of inadvertent human intrusion. Finally, appropriate siting ensures that the site is not prone to disruptive events and to processes unfavourable to long-term stability.

- Long-term Confinement and Radioactive Decay within the Disposal System: Much of the activity initially present 


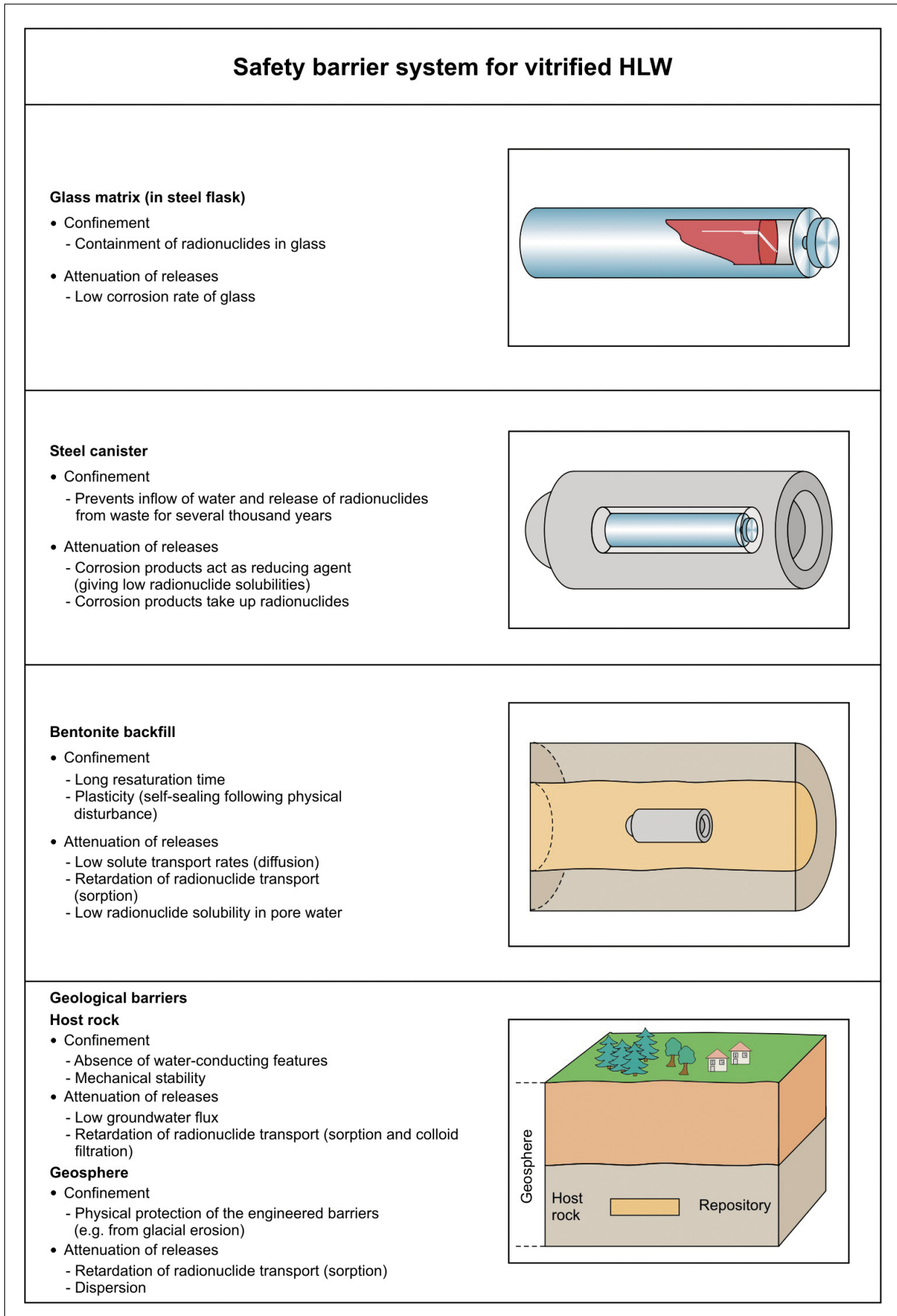

Fig. 3. The system of safety barriers and the multiple safety-relevant functions that each barrier provides in the case of vitrified HLW

decays while the wastes are totally contained within the primary waste containers, particularly in the case of SF and HLW, for which the high integrity steel canisters are expected to remain unbreached for at least 10,000 years. Even after the canisters are breached, the stability of the SF and HLW waste forms in the expected environment, the slowness of groundwater flow and a range of geochemical immobilisation and retardation processes ensure that radionuclides continue to be largely confined within the engineered barrier system and the immediately surrounding rock, so that further radioactive decay takes place.

- Attenuation of Releases to the Environment: Although complete confinement cannot be provided over all relevant times for all radionuclides, release rates of radionuclides from the waste forms are low, particularly from the stable SF and HLW waste forms. Furthermore, a number of processes attenuate releases during transport towards the surface environment, and limit the concentrations of radionuclides in that environment. These include a) radioactive decay during slow transport through the barrier provided by the host rock and b) the spread of released radionuclides in time and space by, for example, diffusion, hydrodynamic dispersion and dilution.

\section{Important Geochemical Parameters and Processes for Repository Safety}

From the viewpoint of (geo)chemistry a number of important parameters and processes have been and still are topics of scientific studies relevant for repository safety. As shown as a graphical summary in Fig. 4, these parameters and processes are:

- Porewater chemistry

- Canister/waste package corrosion

- SF/HLW/waste form dissolution with radionuclides entering the aqueous phase

- Solubility limits for radionuclides in the near field and the geosphere

- Diffusion (+ advection) and sorption of radionuclides in the near field

- Diffusion (+ advection) and sorption of radionuclides in the geosphere

In the following, some selected aspects concerning porewater chemistry, solubility limits and sorption are discussed in detail with specific examples. The phenomenon of glass dissolution is discussed by Curti [17].

\subsection{Porewater Chemistry}

Potential repository sites are foreseen in geological formations with low groundwater flow. Specifically, clay host rocks are characterised by very low groundwater flow. This implies difficulties with respect to the prerequisite of all geochemical modelling for repository safety, i.e. the definition of the porewater chemistry. Whereas sampling and subsequent chemical analyses of surface water, water from wells or groundwater in deep aquifers are routine procedures, the sampling and analysis of porewater in material with a low hydraulic conductivity is an exceedingly difficult task.

If, for example, the water 'flow' in the sampling site of a dense clay formation is only a few drops per day, there is a high probability that the small quantity of water obtained after several weeks of sampling is no longer identical with the original porewater. The original porewater perhaps is not in thermodynamic equilibrium with carbon dioxide of the atmosphere and hence, either some outgassing of $\mathrm{CO}_{2}$ or dissolution of atmospheric $\mathrm{CO}_{2}$ in the water may occur during the sampling. In both cases not only the carbonate concentration in the sampled water changes but also the $\mathrm{pH}$ of the water. These and other sampling artefacts may change the water chemistry of the finally analysed sample considerably. Similar artefacts are encountered in the attempt to obtain porewater by high-pressure squeezing 


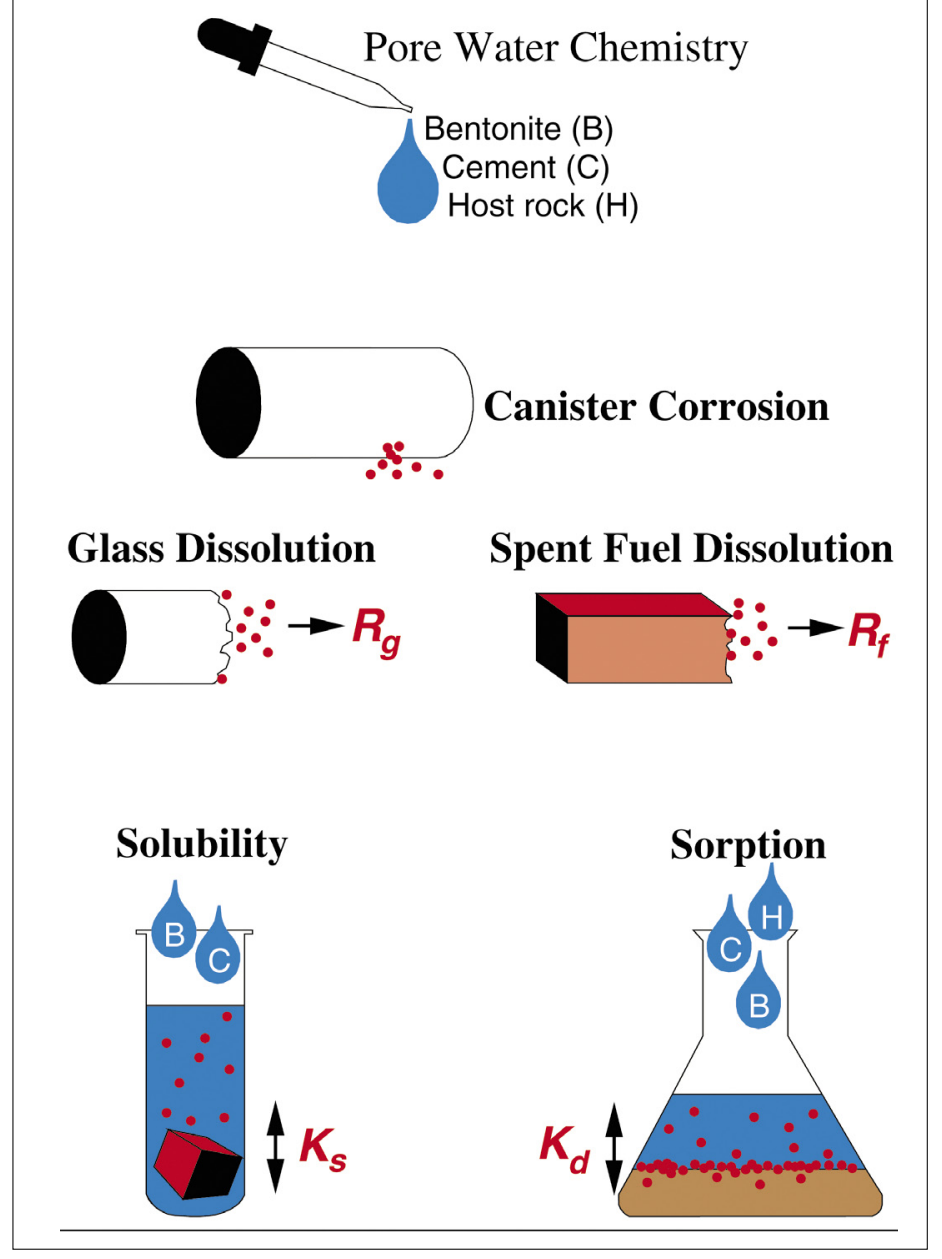

Fig. 4. Important geochemical parameters and processes for repository chemistry. The dissolution parameters $R_{\mathrm{g}}$ and $R_{\mathrm{f}}$ are case specific kinetic rate constants, whereas the elemental solubility limits $K_{s}$ and the sorption coefficients $K_{\mathrm{d}}$ are element and case specific equilibrium constants.

of rock samples or bentonite backfill material.

In summary, the definition of porewater chemistry involves the scrutinising of field data, laboratory experiments, and geochemical modelling, as discussed in several reports [18-20]. Despite all these efforts some uncertainty in key parameters such as $\mathrm{CO}_{2}$ partial pressure and $\mathrm{pH}$ remains and has to be considered in subsequent modelling of solubilities and sorption properties.

Recent research activities in the field of molecular modelling aim at an understanding of the properties of water in highly compacted clay systems on a molecular level with the goal of reducing the uncertainties in the definition of porewaters in these systems.

\subsection{Solubility Limits}

An important feature of repository safety is the fact that radionuclides cannot be dissolved in unlimited quantities in the aqueous phase. Their maximum concentrations are limited by the precipitation of solid phases when the solution becomes oversaturated with respect to a certain radionuclide. These so-called elemental solubility limits, $K_{s}$, can be calculated by thermodynamic modelling assuming that in the long term chemical equilibrium is reached between solids and the aqueous phase.

As an example, the solubility of americium in bentonite porewater [21] is shown in Fig. 5. The above-mentioned uncertainty in the $\mathrm{CO}_{2}$ partial pressure of the bentonite reference porewater is reflected in the $\log _{10} p \mathrm{CO}_{2}$ parameter range of Fig. 5. As a consequence, the calculated solubility of the solid $\mathrm{AmOHCO}_{3}(\mathrm{~s})$ (Fig. 5, left) and the aqueous speciation of americium (Fig. 5, right) vary within certain bounds as shown in the Fig. These uncertainties are considered in subsequent safety calculations [8].

Thermodynamic modelling of solubility limits not only needs parameter ranges of the water chemistry but also a critically reviewed database of chemical thermodynamic constants [22] and careful considerations whether this database is complete with respect to the chemical systems to be modelled [23]. A new feature in the americium example (Fig. 5) is the dominance of an aqueous americium silicate complex in a certain parameter range. Experimental investigations of aqueous silicate complexes of radionuclides commenced a few years ago and are still ongoing.

If chemical thermodynamic constants are too scarce for modelling of a certain system, solubility limits are estimated by scrutinising experimental evidence related to solubility phenomena or by chemical analogies [21][24].

Thermodynamic modelling of solubility limits in safety analyses is based on
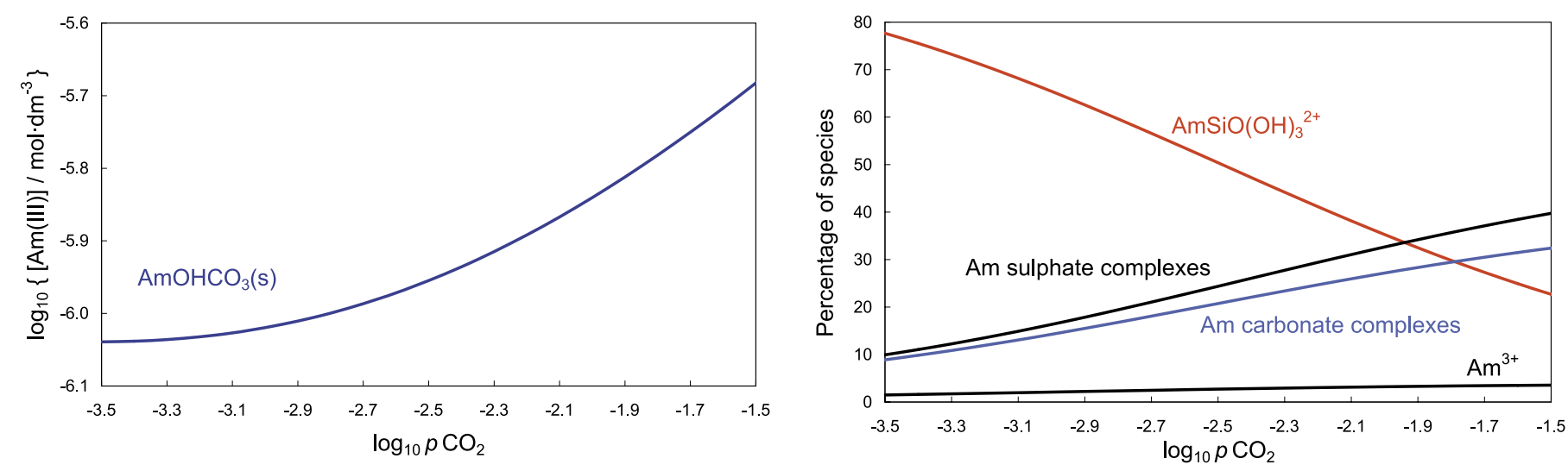

Fig. 5. Americium solubility in bentonite porewater (taken from [21]) 
solubility data for pure solid phases. This procedure leads to maximum solubilities of radionuclides from a thermodynamic point of view. However, most radionuclides are not expected to form pure solid phases but to take part in solid solutions with major host minerals in the repository surroundings. Considering these solid solutions in thermodynamic modelling would result in lower radionuclide concentrations in the aqueous phase.

For example, recent studies of europium forming solid solutions with calcite [25] indicate that the solubility of the chemical analogue americium may not be limited by the pure phase $\mathrm{AmOHCO}_{3}$ (s) (Fig. 5) but by an americium-calcite solid solution. Ongoing research activities aim at obtaining reliable data for safety relevant chemical systems with the goal of establishing a thermodynamic database for solid solutions.

\subsection{Sorption}

A further important feature of repository safety is the observation that radionuclides are retarded in their migration through the near field and geosphere of a geological repository by the phenomenon of sorption at the water-rock interface. From a purely phenomenological point of view the experimentally observed distribution of trace amounts of radionuclides between the aqueous phase and a solid phase (measured as the distribution coefficient $R_{\mathrm{d}}$ ) can be interpreted as a sorption process (with a coefficient $K_{\mathrm{d}}$ ) if this process is reversible, i.e. if the radionuclides can be desorbed from the solid phase by lowering their concentration in the aqueous phase.

As an example, the americium sorption edges on the clay mineral montmorillonite [26] are shown in Fig. 6. (An americium sorption edge is the solid-water distribution of trace amounts of americium as a function of $\mathrm{pH}$.) The strong effect of ionic strength (i.e. the concentration of the background electrolyte $\mathrm{NaClO}_{4}$ ) on the americium sorption at low $\mathrm{pH}$ can be interpreted in terms of an ion-exchange process, whereas sorption in the alkaline $\mathrm{pH}$ region could be modelled with the concept of surface complexation.

For safety analyses sorption databases were prepared [27-29] either based on batch sorption experiments, as shown in Fig. 6, or based on geochemical sorption models also supported by experimental evidence, or in cases where no reliable experimental data were available, based on chemical analogies [30].

In recent safety analyses radionuclide distributions at the water-rock interface generally were assumed to be reversible, and thus leading to a minimum retardation of radionuclides. The reality, however, might be better represented by a continuum of processes from pure surface phenomena to solid solution formation, which most

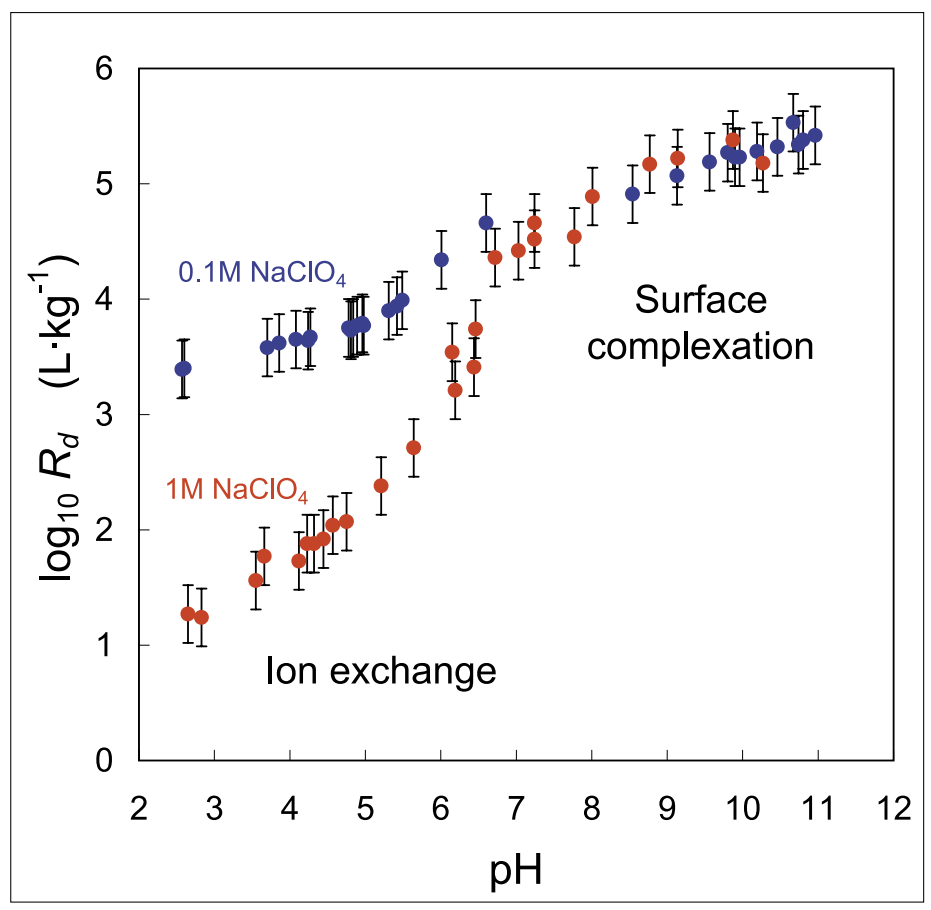

Fig. 6. Americium sorption edges on montmorillonite (data taken from [26])

probably results in a considerably stronger retardation of radionuclides in the geosphere than estimated by current models.

Ongoing research activities aim at a consistent geochemical sorption model for all radionuclides of interest with the goal of establishing a thermodynamic sorption database [31]. A farther reaching goal is a consistent thermodynamic model of the continuum of processes from pure surface phenomena to solid solution formation.

\section{Received: August 10, 2005}

[1] 'Kernenergiegesetz vom 21.03.2003' KEG, Systematische Sammlung des Bundesrechts SR 732.1, Switzerland, 2003.

[2] 'Disposal concepts for radioactive waste: Final report', Expertengruppe Entsorgungskonzepte für radioaktive Abfälle / Expert group on disposal concepts for radioactive waste (EKRA). On behalf of the Federal Department for the Environment, Transport, Energy and Communication, 2000.

[3] 'Technical overview of the SAFIR 2 report: Safety assessment and feasibility interim report 2', NIROND-2001-05E. ONDRAF, Brussels, Belgium, 2001.

[4] T. Vieno, H. Nordman, 'Safety assessment of spent fuel disposal in Hästholmen, Kivetty, Olkiluoto and Romuvaara: TILA99', Posiva Report 99-07. Posiva Oy, Helsinki, Finland, 1999.

[5] 'Dossier 2001 Argile sur l'avancement des études et recherches relatives à la faisabilité d'un stockage de déchets à haute activité et à vie longue en formation géologique profonde: Rapport de synthèse', ANDRA, Châtenay-Malabry, France, 2001.
[6] 'H12: Project to Establish the Scientific and Technical Basis for HLW Disposal in Japan: Second Progress Report on Research and Development for the Geological Disposal of HLW in Japan', JNC TN1410 2000-001. JNC, Tokyo, Japan, 2000.

[7] 'Deep repository for spent nuclear fuel: SR 97: Post-closure safety: Main report', Technical Report TR-99-06. SKB, Stockholm, Sweden, 1999.

[8] 'Project Opalinus Clay: Safety Report. Demonstration of disposal feasibility for spent fuel, vitrified high-level waste and long-lived intermediate-level waste (Entsorgungsnachweis)', Nagra Technical Report NTB 02-05. Nagra, Wettingen, Switzerland, 2002.

[9] J.A. McNeisch, 'Total system performance assessment for the site recommendation: Yucca Mountain Project', TDR-WIS-PA000001 REV 00 ICN 01. U.S. Department of Energy, Yucca Mountain Project, USA (CD), 2000.

[10] P.A. Witherspoon, G.S. Bodvarsson, Eds., 'Geological challenges in radioactive waste isolation: third worldwide review', LBNL49767. Ernest Orlando Lawrence Berkeley National Laboratory, Berkeley, 2001.

[11] This is in line with the Swiss Nuclear Energy Law [1], which contains a 10-year moratorium for any future reprocessing of spent fuel.

[12] A centralised interim storage facility for all waste types.

[13] A facility for SF, HLW, and L/ILW operated by the Beznau nuclear power plant.

[14] 'Bundeszwischenlager', a facility for radioactive waste from medicine, industry, and research, located at the same site as 
ZWILAG and operated by the Paul Scherrer Institute (PSI) on behalf of the Swiss Federal Office of Health (BAG).

[15] Facilities for operational waste located on the grounds of the nuclear power plants.

[16] Termed SMA (schwach- und mittelaktive Abfälle) in German.

[17] E. Curti, 'Glass dissolution parameters: Update for "Entsorgungsnachweis", Nagra Technical Report NTB 02-21 and PSI Bericht Nr. 03-18, Paul Scherrer Institut, Villigen, Switzerland, 2003.

[18] E. Curti, P. Wersin, 'Assessment of Porewater Chemistry in the Bentonite Backfill for the Swiss SF/HLW Repository', Nagra Technical Report NTB 02-09. Nagra, Wettingen, Switzerland, 2002.

[19] F.J. Pearson, 'Benken reference water chemistry', Unpubl. Nagra Internal Report. Nagra, Wettingen, Switzerland, 2002.

[20] M.H. Bradbury, B. Baeyens, 'Porewater chemistry in compacted resaturated MX80 bentonite', J. Cont. Hydr. 2003, 61, 329-338.

[21] U. Berner, 'Project Opalinus Clay: Radionuclide concentration limits in the near field of a repository for spent fuel and vitrified high-level waste', Nagra Technical Report NTB 02-10 and PSI Bericht Nr. 0222, Paul Scherrer Institut, Villigen, Switzerland, 2002.

[22] W. Hummel, U. Berner, E. Curti, F.J. Pearson, T. Thoenen, 'Nagra/PSI Chemical Thermodynamic Database 01/01', Nagra
Technical Report NTB 02-16 and Universal Publishers/uPublish.com, Parkland, Florida, USA, 2002.

[23] W. Hummel, U. Berner, 'Application of the Nagra/PSI TDB 01/01: Solubility of Th, U, Np and Pu', Nagra Technical Report NTB 02-12. Nagra, Wettingen, Switzerland, 2002.

[24] U. Berner, 'Project Opalinus Clay: Radionuclide concentration limits in the near field of a repository for long-lived intermediate-level waste', Nagra Technical Report NTB 02-22 and PSI Bericht Nr. 02-26, Paul Scherrer Institut, Villigen, Switzerland, 2003.

[25] E. Curti, D. Kulik, J. Tits, 'Solid solutions of trace $\mathrm{Eu}(\mathrm{III})$ in calcite: Thermodynamic evaluation of experimental data over a wide range of $\mathrm{pH}$ and $\mathrm{pCO}_{2}$, Geochim. Cosmochim. Acta 2005, 69, 1721-1737.

[26] L. Gorgeon, 'Contribution à la modélisation physico-chimique de la retention de radioélements à vie longue par des matériaux argileux', Unpublished $\mathrm{PhD}$ Thesis. Université Paris 6, 1994.

[27] M.H. Bradbury, B. Baeyens, 'Near field sorption data bases for compacted MX-80 bentonite for performance assessment of a high level radioactive waste repository in Opalinus Clay host rock', Nagra Technical Report NTB 02-18 and PSI Bericht Nr. 03-07, Paul Scherrer Institut, Villigen, Switzerland, 2003.
[28] M.H. Bradbury, B. Baeyens, 'Far field sorption data base for performance assessment of a high level radioactive waste repository in an undisturbed Opalinus Clay host rock', Nagra Technical Report NTB 02-19 and PSI Bericht Nr. 03-08, Paul Scherrer Institut, Villigen, Switzerland, 2003.

[29] E. Wieland, L.R. Van Loon, 'Cementitious near field sorption data base for performance assessment of an ILW repository in Opalinus Clay', Nagra Technical Report NTB 02-20 and PSI Bericht Nr. 03-06, Paul Scherrer Institut, Villigen, Switzerland, 2003

[30] P. Wersin, B. Schwyn, 'Project Opalinus Clay: Integrated approach for the development of geochemical databases used for safety assessment', Nagra Technical Report NTB 03-06. Nagra, Wettingen, Switzerland, 2004.

[31] M.H. Bradbury, B. Baeyens, 'Modelling the sorption of $\mathrm{Mn}(\mathrm{II}), \mathrm{Co}(\mathrm{II}), \mathrm{Ni}(\mathrm{II})$, $\mathrm{Zn}(\mathrm{II}), \mathrm{Cd}(\mathrm{II}), \mathrm{Eu}(\mathrm{III}), \mathrm{Am}(\mathrm{III}), \mathrm{Sn}(\mathrm{IV})$, $\mathrm{Th}(\mathrm{IV}), \mathrm{Np}(\mathrm{V})$ and U(VI) on montmorillonite: Linear free energy relationships and estimates of surface binding constants for some selected heavy metals and actinides', Geochim. Cosmochim. Acta 2005, 69, 875-892. 